\title{
Jambal roti characteristics: a traditional fermented fish from Rembang, Central Java
}

\author{
${ }^{1,2}$ Karyantina, M., ${ }^{3}$ Anggrahini, S., ${ }^{3,4}$ Utami, T. and ${ }^{3,4 *}$ Rahayu, E.S. \\ ${ }^{1}$ Doctoral Programme in Agricultural Technology, Universitas Gadjah Mada, Jl. Flora No 1, Bulaksumur, \\ Caturtunggal, Yogyakarta \\ ${ }^{2}$ Faculty of Technology and Food Industry, Slamet Riyadi University, Sumpah Pemuda Street No 18, Joglo, \\ Surakarta \\ ${ }^{3}$ Faculty of Agricultural Technology, Universitas Gadjah Mada, Jl. Flora No 1, Bulaksumur, Caturtunggal, \\ Yogyakarta \\ ${ }^{4}$ Center for Food and Nutrition Studies, Universitas Gadjah Mada, Yogyakarta, Indonesia
}

\begin{abstract}
Article history:
Received: 7 December 2020

Received in revised form: 14

February 2021

Accepted: 2 October 2021

Available Online: 17 October

2021
\end{abstract}

Keywords:

Jambal roti,

Fermented fish,

Proximate,

Microbiological

\section{DOI:}

https://doi.org/10.26656/fr.2017.5(S2).011

\begin{abstract}
Jambal roti is a fermented fish product, commonly found in some regions in Java Island, Indonesia, such as Pekalongan, Cilacap, Pangandaran, Rembang, and along the northern coast. The raw sea catfish (Arius thalassinus) were traditionally processed by salting (salt amounting to $30 \%$ of the fish weight) then sun-drying. This study examined the microbiological and chemical characteristics of jambal roti produced in the Rembang Regency. Samples were taken from artisanal jambal roti producers during the making process. The proximate and chemical (final product of jambal roti) test results showed that the $\mathrm{a}_{\mathrm{w}}(0.723)$ and salt contents $(18.166 \%)$ of the samples met the SNI 2721:2009, but the water $(48.534 \%)$, ash $(18.022 \%)$, and dissolved protein contents $(5.494 \%)$ were above their allowable levels. The microbial analysis revealed that despite the absence of Escherichia coli and Salmonella spp. in the product, the total aerobic bacteria (APC) $\left(6.6 \times 10^{2} \mathrm{CFU} / \mathrm{g}\right)$ and yeast and mold contamination $\left(1.4 \times 10^{3} \mathrm{CFU} / \mathrm{g}\right)$ found in the samples were above the standards.
\end{abstract}

\section{Introduction}

Salted fish is made of raw fish cured which preserved by adding a large amount of salt. Fish is first cleaned and placed in a container, then sprinkled with dry salt or immersed in a concentrated salt solution. Because of the difference in concentration and osmotic pressure, salt crystals draw liquids out of the microbial cells while seeping into fish flesh. This process continues until the balance between the salt concentration outside and inside the fish is achieved. High salt concentration and cell shrinkage stop the autolysis process and inhibit bacterial growth in fish (Amir, 2014).

Jambal roti is a popular salted fish popular on Java Island, with production centers distributed in Pekalongan, Cilacap, Cirebon, Pangandaran, Rembang, and along the northern coast. It is usually made of giant sea catfish (Arius sp). The name jambal roti came from the change in its sensory characteristics after frying, where the texture becomes crumbly, like bread. Its popularity mainly stems from its distinctive flavor, smell, and sand-like texture (Irianto, 2012).

Rahayu et al. (1992) argued that the making of jambal roti involves a fermentation process, that is, the biological or semi-biological breakdown of complex compounds, especially proteins, into simple ones. During the fermentation process, the fish protein is hydrolyzed into amino acids and peptides, and then the amino acids are further disintegrated into other components that form the taste.

Jambal roti is produced traditionally, and, as yet, this process does not meet the quality requirements issued by the BSN-National Standardization Agency of Indonesia. Moreover, every region has its own making technique (i.e., wet or dry process), causing differences in product qualities and characteristics. To date, because there is no national quality standard for jambal roti, its production still aims to comply with that of salted fish, which, unlike jambal roti, tends to have higher moisture content.

This research examined the characteristics of the jambal roti produced by artisans in Bonang Village, 
Rembang Regency, Central Java. The making of jambal roti starts with cleaning the fish, disposing of intestines and head, cutting, salting (for three days), washing, then sun-drying (for three days).

\section{Materials and methods}

\subsection{Sampling}

Samples were taken from jambal roti artisans in Bonang Village, Rembang Regency, Central Java, during the production. In this village, the production process includes cleaning, 3-days salting, washing, and 3-days sun-drying. There were six sampling points of time: on Day 1 (F1), Day 2 (F2), and Day 3 (F3) of salting and on Day 1 (F4), Day 2 (F5), and Day 3 (F6) of drying. Each of these samples was collected in a clean plastic bag from the freshly produced sections, put into a cooler-box containing ice cubes, transported to the Microbiology Laboratory of the Center for Food and Nutrition Studies (Universitas Gadjah Mada, Yogyakarta), and preserved at $-20^{\circ} \mathrm{C}$ until before the analysis.

\subsection{Microbiological analyses}

Media for microbiological analysis were the PlateCount Agar (PCA, Merck), de Man Rogosa and Sharpe agar (MRS, Merck), Dichloran-Glycerol 18\% agar base (DG18, Oxoid), Violet Red Bile Agar (VRBA, Merck), and Salmonella Shigella Agar (SSA, Merck). These growing media served different quantification purposes: PCA for the total aerobic plate count (APC), MRS for lactic acid bacteria, DG18 for yeast and mold, VRBA for coliform bacteria, and SSA for Salmonella and Shigella bacteria.

Approximately $1 \mathrm{~g}$ of each sample was placed in 9 $\mathrm{mL}$ of dilution medium $(0.85 \% \mathrm{NaCl})$ and then diluted until $10^{-6}$. Afterward, the plate-count method was applied in duplicate to the diluted sample on the media, then incubated for $36 \mathrm{hrs}$ on $37^{\circ} \mathrm{C}$. After $36 \mathrm{hrs}$, the colony was counted.

\subsection{Chemical analyses}

The proximate analysis measured the moisture content (by thermogravimetry) (AOAC, 1970), ash content (the oven method) (AOAC, 1970), total protein content (micro-Kjeldahl) (Sudarmadji et al., 1997), and fat content (Soxhlet method) (AOAC, 1990). Meanwhile, the chemical analysis measured, $\mathrm{NaCl}$ levels (Kohman) (Apriyantono, 1989), water activity, and $\mathrm{pH}$ (Apriyantono, 1989). As for the proteolytic activities, the skim milk agar method (Prihanto et al., 2013) was used for the qualitative evaluation, whereas the Bergmeyer and Grassl method was for the quantitative analysis (Yusufa et al., 2012).

\section{Results and discussion}

3.1 Microbiological quality of jambal roti during fermentation

Jambal roti is a fermented fish product that is preserved using high salt content (30\%) and still traditionally produced. The traditional technique may cause microbiological and chemical contaminations during the salting and sun-drying. Until now, there is no national quality standard for jambal roti, its production quality standard refers to the standard, for salted fish, which, unlike jambal roti, tends to have higher moisture content.

Table 1 shows the microbiological analysis results of jambal roti during the fermentation process. The TPC ranged from $1.2 \times 10^{3}$ to $6.0 \times 10^{6} \mathrm{CFU} / \mathrm{g}$. At the first stage of fermentation (i.e., salting process), it increased from $2.4 \times 10^{4}(\mathrm{~F} 1)$ to $7.4 \times 10^{5} \mathrm{CFU} / \mathrm{g}(\mathrm{F} 3)$, and this is possible because microbes like halophilic/halotolerant bacteria are resistant to high salt levels and, thus, can survive in this environment. Rinto (2010) confirmed a shift in the dominant bacteria in fish during the salting process, from g-negative to g-positive, one of which was lactic acid bacteria. This statement is in line with the current study results, where the number of lactic acid bacteria multiplied from $1.2 \times 10^{3} \mathrm{CFU} / \mathrm{g}$ at the beginning of fermentation to $4.0 \times 10^{4} \mathrm{CFU} / \mathrm{g}$ at the end product.

High content of salt used in the fermentation process means that more water is removed from fish flesh and replaced by salt molecules. Water removal reduces moisture content and water activity $\left(\mathrm{a}_{\mathrm{w}}\right)$, thus inhibiting pathogenic and non-pathogenic bacterial growth. This theory also applies to this study, in which no pathogenic

Table 1. Microbiological characteristics of jambal roti during fermentation

\begin{tabular}{cccccc}
\hline Day of Fermentation & $\begin{array}{c}\text { APC } \\
(\mathrm{CFU} / \mathrm{g})\end{array}$ & $\begin{array}{c}\text { Yeast and mold } \\
(\mathrm{CFU} / \mathrm{g})\end{array}$ & $\begin{array}{c}\text { E. coli } \\
(\mathrm{CFU} / \mathrm{g})\end{array}$ & $\begin{array}{c}\text { Salmonella } \text { spp. } \\
(\mathrm{CFU} / \mathrm{g})\end{array}$ & $\begin{array}{c}\text { Lactic acid bacteria } \\
(\mathrm{CFU} / \mathrm{g})\end{array}$ \\
\hline F1 & $2.4 \times 10^{4}$ & $1.7 \times 10^{2}$ & $\mathrm{ND}$ & $\mathrm{ND}$ & $1.2 \times 10^{3}$ \\
F2 & $3.3 \times 10^{4}$ & $1.2 \times 10^{2}$ & $\mathrm{ND}$ & $\mathrm{ND}$ & $1.4 \times 10^{3}$ \\
F3 & $7.4 \times 10^{5}$ & $1.1 \times 10^{2}$ & $\mathrm{ND}$ & $\mathrm{ND}$ & $2.8 \times 10^{3}$ \\
F4 & $1.2 \times 10^{3}$ & $3.3 \times 10^{1}$ & $\mathrm{ND}$ & $\mathrm{ND}$ & $3.0 \times 10^{3}$ \\
F5 & $6.0 \times 10^{6}$ & $1.4 \times 10^{2}$ & $\mathrm{ND}$ & $\mathrm{ND}$ & $3.3 \times 10^{3}$ \\
F6 & $8.8 \times 10^{3}$ & $9.4 \times 10^{1}$ & $\mathrm{ND}$ & $\mathrm{ND}$ & $4.0 \times 10^{4}$ \\
\hline
\end{tabular}

F1: Day 1 of salting, F2: Day 2 of salting, F3: Day 3 of salting, F4: Day 1 of drying, F5: Day 2 of drying, F6: Day 3 of drying. 
bacteria (Escherichia coli and Salmonella-Shigella) were detected during fermentation. The quality standards of salted fish set by the BSN-National Standardization Agency (2009) require the maximum number of E. coli to be less than 0 Most Probable Number (MPN)/g and the g-negative Salmonella bacteria to be $25 \mathrm{CFU} / \mathrm{g}$, meaning that the jambal roti has met these requirements. Meanwhile, the number of yeast and mold (nonpathogenic bacteria) decreased by one log during fermentation. At the end of this process, the TPC and yeast and mold was $8.8 \times 10^{3}$ and $9.4 \times 10^{1} \mathrm{CFU} / \mathrm{g}$, respectively, or within the allowable non-pathogenic bacterial presence in salted fish, which is a maximum of $10^{5} \mathrm{CFU} / \mathrm{g}$.

In fish, there are natural bacteria, these bacteria play a role in fish fermentation so that the chemical and microbiological composition will change due to the activity of these bacteria. Spontaneous fermentations utilize natural microorganisms contained in the raw material as a starter to trigger protease production during fermentation. The natural microorganisms help to convert the protein of fish flesh to simple peptides (Nadiah et al., 2014). The product hydrolysate of Rohu fish fermentation showed that the number of lactic acid bacteria ranged from 5.83 to $7.25 \log \mathrm{CFU} / \mathrm{mL}$, and some lactic acid bacteria could be isolated from these products (Pediococcus sp.). The identified lactic acid bacteria isolates showed excellent proteolytic activity and phosphohydrolase activity (Siddegowdaa et al., 2017). This result shows that natural lactic acid bacteria play a very important role in fish fermentation, where these bacteria have halotolerant properties, so they can grow at high salt levels.

Like jambal roti, momone is a traditional fermented fish product from Ghana, whose salting process (15$40 \%$ ) takes 3-8 days, and the subsequent drying lasts for three days (Anihouvi, 2012). Sanni (2002) found that momone is dominated by Bacillus, Lactobacillus, Pseudomonas, Pediococcus, Staphylococcus, Klebsiella, Debaryomyces, Hansenula, and Aspergillus. Rahayu (2003) has isolated lactic acid bacteria from several fermented foods (fish, vegetables, and fruit) and found that several lactic acid bacteria isolated from salted fish (from Demak, Central Java) consisted of four Lactobacillus strains, one Streptococcus strain, and seven Leuconostoc strains. Further molecular identification revealed Lactobacillus plantarum (two isolates), Lactobacillus acidophilus (two isolates), and Streptococcus thermophilus (one isolate).

Some bacteria can be isolated from salted fish, high salt content, water content and low Aw are able to inhibit the growth of pathogens, because only a few bacteria are able to grow at high salt levels, for example, lactic acid bacteria. Lactic acid bacteria in fish, play a role in the degradation of fish protein by means of the protease enzyme which is able to break down fish protein, into amino acids and peptides. The results of this study indicate that jambal roti is a safe product for consumption, due to its high salt content, low water content and low water activity. Pathogenic bacteria are not able to grow well at high salt content and water content and low water activity. Fish products are easily damaged, so one of the efforts to preserve them is by salting. Jambal roti is a fish product that is preserved using salt and is continued with the drying process so that it can be stored for a long period of time (more than 6 months).

Karyantina et al. (2020), has isolated bacteria from jambal roti. The jambal roti was dominated by bacteria with round-shape tetrad bacteria, suspected as Pedicococcus, and a few rod-shaped bacteria, suspected as Lactobacillus. Based on the previous studies, the bacteria contributing to salted fish fermentation are Lactobacillus and Pediococcus. As indicated by the initial characterization, it is highly likely that the bacteria contributing to the fermentation of jambal roti are also Lactobacillus and Pediococcus. Lactobacillus and Pediococcus are known to produce bacteriocin (pediocin), which can suppress the growth of pathogenic bacteria, such as E. coli and Salmonella. The presence of lactic acid bacteria in jambal roti can produce bacteriocins, making the product quite safe from pathogenic bacteria

\subsection{Chemical analysis of jambal roti}

The final product characteristic of jambal roti is moisture content $48.534 \pm 0.501 \%$, ash content $18.022 \pm 0.158 \%$, protein content (total N) $5.494 \pm 0.264 \%$, water activity $0.723 \pm 0.008, \quad \mathrm{NaCl}$ content $18.166 \pm 0.332 \%$ and fat $0.209 \pm 0.052 \%$. The water content, salt content and Aw of the final product are low enough so that only a few microorganisms can grow and pathogenic bacteria are not able to grow properly under these conditions.

Table 2 shows the chemicals analysis results of jambal roti during the fermentation process. During the fermentation process, the moisture content decreased from $64.162 \%$ (F1) to $45.518 \%$ (F6) because of the increasing salt drawing liquids out of the fish flesh. Reductions in water activity (Aw), from 0.720 (F1) to 0.590 (F6). According to Essuman (1992), at $\mathrm{a}_{\mathrm{w}}=0.59$ and $\mathrm{NaCl}>17 \%$, only certain microorganisms can grow, including halophilic and xerophilic bacteria. The moisture content ranged between $45.518 \%$ and $64.162 \%$, indicating that the jambal roti contains more moisture 
Table 2. Chemical characteristics of jambal roti during fermentation

\begin{tabular}{cccccc}
\hline Day of Fermentation & $\begin{array}{c}\text { Moisture content } \\
(\%)\end{array}$ & $\begin{array}{c}\text { Ash } \\
(\%)\end{array}$ & $\begin{array}{c}\text { Protein } \\
(\%)\end{array}$ & $\mathrm{a}_{\mathrm{w}}$ & $\mathrm{pH}$ \\
\hline F1 (salting) & $64.162 \pm 0.048$ & $11.241 \pm 0.010$ & $18.081 \pm 0.050$ & $0.720 \pm 0.00$ & 6.14 \\
F2 (salting) & $62.682 \pm 0.005$ & $14.092 \pm 0.019$ & $19.825 \pm 0.013$ & $0.690 \pm 0.00$ & 6.04 \\
F3 (salting) & $61.205 \pm 0.008$ & $16.235 \pm 0.035$ & $19.254 \pm 0.037$ & $0.660 \pm 0.00$ & 6.13 \\
F4 (drying) & $60.831 \pm 0,069$ & $18.601 \pm 0.030$ & $18.780 \pm 0.021$ & $0.630 \pm 0.00$ & 6.45 \\
F5 (drying) & $49.387 \pm 0.008$ & $21.372 \pm 0.013$ & $24.860 \pm 0.028$ & $0.595 \pm 0.007$ & 6.53 \\
F6 (drying) & $45.518 \pm 0.033$ & $20.221 \pm 0.042$ & $24.472 \pm 0.177$ & $0.590 \pm 0.00$ & 6.18 \\
\hline
\end{tabular}

F1: Day 1 of salting, F2: Day 2 of salting, F3: Day 3 of salting, F4: Day 1 of drying, F5: Day 2 of drying, F6: Day 3 of drying.

than the quality standard for salted fish, namely $40 \%$, triggering microbial growth. The increased salt content indicates the molecular penetration is more perfect in the meat of fish during fermentation. At the beginning of fermentation, the salt granules surround the fish flesh. As the fermentation time increases, the salt grains become dissolved because of the high surface moisture of fish meat. When solubility reaches saturation point, the salt penetrates and rejects the water molecule out of the fish meat. Salt can reduce the water holding capacity of fish meat so that the shelf life of a fermented fish product is longer. Besides being hygroscopic, salt also acts as a bacteriostatic agent against pathogenic and spoilage bacteria in fish meat (Mahulette, 2018)

The results from Nofiani et al. (2019) showed that the water content of buduk was around $52.35 \%$, which is higher than jambal roti products. However, in the process of making buduk, besides salt, sugar and rice are added as a source of carbohydrates, so that the product tends to be like pasta.

According to prior studies of similar products, momone $(54.33 \%)$ has higher moisture content than jambal roti (Sanni, 2002), but fassiekh had a lower moisture content (46.34\%) (Osman et al., 2012). Meanwhile, the water activity, varying from 0.590 (F6) to $0.720(\mathrm{~F} 1)$, is below the upper threshold in the quality standard, namely 0.78. Research on fermented fish products by salting (without adding a source of carbohydrates) followed by the drying process is quite limited. Most fermented fish products are salted with salt plus a source of carbohydrates such as rice and tubers. Or the final product in paste form. The product of jambal roti is one of the fermented fish products with a salting process followed by drying, similar products are momone (Ghana) and Fassiekh (Sudan).

The ash content of jambal roti during the fermentation increased from $11.241 \%$ (F1) to $20.221 \%$ (F6), which far exceeds its allowable presence in salted fish $(1.5 \%)$. This result was because the amount of salt $(\mathrm{NaCl})$ seeping into fish flesh increased; in this context, salt contributes minerals to food products. It is consistent with the $\mathrm{NaCl}$, i.e., $84.09 \%$, and the use of technical salt produced by salt farmers. Similarly, momone also has an ash content of $11.72 \%$ and a salt content of $300 \mathrm{~g} / \mathrm{kg}$ (Sanni, 2002), while fassiekh has an ash content of 20.53\% (Osman et al., 2012).

The total protein raw fish is $20.885 \%$. The total protein content increased from $18.081 \%$ (F1) to $24.472 \%$ (F6) because, during fermentation, the fish protein was hydrolyzed into amino acids and peptides, then amino acids. Protein analysis uses the micro Kjeldahl method so that what is measured is the total Nitrogen in the protein or which has been hydrolyzed into simpler molecules, namely amino acids and peptides. Protein hydrolysis becomes a simpler compound, one of which is due to the presence of indigenous bacteria in fish that have the ability to break down proteins (proteolytic bacteria). So that the complete breakdown of amino acids and peptides can be measured in the analysis of total N. At this range, the protein content of the jambal roti does not satisfy the national quality standard of salted fish, namely at least $30.20 \%$. It is almost the same as the protein content of momone that is $16.8-21.9 \%$ (Sanni, 2002). In the final product, the protein content decreased to $5.494 \pm 0.264 \%$, possibly because the amino acids and peptides had undergone decomposition so they were not measured during the analysis. Protein that has been hydrolyzed during the fermentation process causes the product to be digested more easily by the body and causes a distinctive flavor from the product.

Apart from moisture, ash, and protein contents and water activity, the proximate analysis also measured the $\mathrm{pH}$ of the jambal roti during six days of fermentation. Table 2 shows that the $\mathrm{pH}$ was in the range of 6.04-6.53. Similar products, momone (Sanni, 2002) and fassiekh (Osman et al., 2012), also have $\mathrm{pH}$ values of \pm 6 . A low $\mathrm{pH}$ optimizes bacteriocin activities, which are responsible for the low population size of pathogenic $(E$. coli) and non-pathogenic bacteria. Also, since only a few pathogenic microbes can grow well in such $\mathrm{pH}$ range, this further supports the conclusion that the bacteria dominating the jambal roti are bacteriocin producers like Lactobacillus and Pediococcus.

\subsection{Proteolytic activity}

The jambal roti produced in the Rembang Regency 
has distinctive characteristics because it is made by salting then drying method. In its salting and drying processes, the protein becomes simple molecules. For this reason, the indigenous bacteria should have a role in protein breakdown, as indicated by proteolytic activities during fermentation. Prihanto et al. (2013) have isolated three bacteria exhibiting proteolytic activities from the jambal roti produced by a home industry in Bandung (West Java, Indonesia).

Several studies have shown that the proteolytic activity of lactic acid bacteria can degradation of muscle protein and sarcoplasmic protein in fish (Fadda et al., 1999; Fadda et al., 2010; Sriphochanart dan Wanwisa, 2010; Xu et al., 2010). Several species L. plantarum are known to have extracellular protease (Marathe dan Ghos, 2009; Strahinic et al., 2010). Extracellular proteinases were found on L. pentosus and L. plantarum strains from cheese isolates (De-Angelis et al., 2001). The qualitative test used skim milk agar media because milk contains many nutrients and is thereby an appropriate medium for bacterial growth. Casein is a milk protein consisting of phosphoproteins that bind to calcium to form calcium salts (calcium calcinate). These molecules are quite large and do not dissolve in water and form colloids. The resulting suspension is white and can be directly observed when suspended in solid media culture (Pakpahan, 2009).

The clear zone that forms around the bacterial colony in the medium is a sign of loss of casein particles or isolates that can utilize casein as a source of nutrition (Huang et al., 2006). Extracellular proteolytic enzymes produced by bacteria hydrolyze casein into soluble peptides and amino acids and disintegrate various longchain carbohydrates, lipids, and proteins into short-chain units or simpler compounds (Yusufa et al., 2012). Figure 1 shows an example of the proteolytic activity of the bacteria in jambal roti. The clear zone indicates that the bacteria in question can produce extracellular proteases that exhibit proteolytic activities, i.e., the breakdown of casein in the skim milk agar medium. The wider the clear zone's diameter, the stronger the proteolytic activity. Only halophilic lactic acid bacteria with proteolytic properties can grow in highly saline environments (salt content $=30 \%$ ) formed during the salting process; not all bacteria can tolerate high salt levels.

Table 3 shows the proteolytic activities of two isolates of jambal roti on Day 2 of salting (F2) and Day 1 of drying (F4). Isolate F4 with a $100 \mu \mathrm{L}$ culture concentration produced a clear zone with a diameter of $2.195 \mathrm{~cm}$. This qualitative evaluation result is in line with the highest proteolytic activity measured in the quantitative analysis, 2.279 Units $/ \mathrm{mL}$ with a cell count of $1.28 \times 10^{9} \mathrm{CFU} / \mathrm{mL}$. Bacteria show high proteolytic activities in the logarithmic phase, at which cells have optimum conditions for metabolism and reproduction (Yunita, 2012). On Day 1 of drying (F4), the fermentation and protein degradation continued, allowing the bacteria to multiply to a large population. Based on the research results, it shows that jambal roti has a proteolytic activity that is able to break down protein into simpler components such as amino acids and peptides, where there is a role for natural bacteria in fish. These components will form a distinctive flavor on the product.

\section{Conclusion}

The jambal roti produced traditionally in the

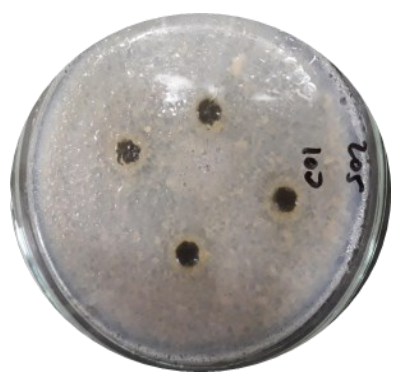

F2 culture isolates with $100 \mu \mathrm{L}$ concentration

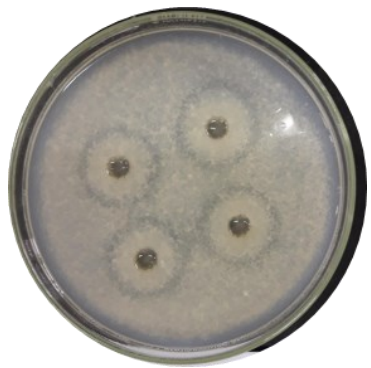

F4 culture isolates with $100 \mu \mathrm{L}$ concentration

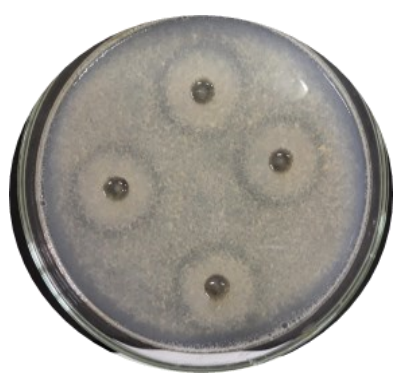

Jambal roti culture isolates with $100 \mu \mathrm{L}$ concentration

Figure 1. Proteolytic activities (qualitative evaluation) of jambal roti

Table 3. Proteolytic activities of jambal roti

\begin{tabular}{|c|c|c|c|c|c|c|}
\hline \multirow{3}{*}{ No } & \multirow{3}{*}{ Isolates } & \multirow{3}{*}{$\begin{array}{c}\text { Proteolytic } \\
\text { activities }\end{array}$} & \multicolumn{3}{|c|}{ Qualitative analysis results } & \multirow{3}{*}{$\begin{array}{c}\text { Quantitative } \\
\text { analysis results } \\
(\mathrm{U} / \mathrm{mL})\end{array}$} \\
\hline & & & \multicolumn{3}{|c|}{$\begin{array}{l}\text { The clear zone diameter on the skim } \\
\text { milk agar media }(\mathrm{cm})\end{array}$} & \\
\hline & & & $50 \mu \mathrm{L}$ & $75 \mu \mathrm{L}$ & $100 \mu \mathrm{L}$ & \\
\hline 1 & $\mathrm{~F} 2$ & + & 0.700 & 1.000 & 1.225 & 2.022 \\
\hline 2 & F4 & + & 0.600 & 2.070 & 2.195 & 2.279 \\
\hline 3 & Jambal roti & + & 0.350 & 0.700 & 1.475 & 1.825 \\
\hline
\end{tabular}


Rembang Regency (Central Java, Indonesia) has met the microbiological, proximate, and chemical requirements set in the Indonesian National Standard (SNI) 2721:2009 for salted fish, except for ash, moisture, and dissolved protein contents. The jambal roti is also safe for consumption because pathogenic bacteria do not grow in conditions of high salt levels and low Aw.

\section{Conflict of interest}

The authors declare no conflict of interest.

\section{Acknowledgments}

This work was funded under the Doctoral Dissertation Research (PDD) grant scheme by the Ministry of Science, Research, and Technology of the Republic of Indonesia in 2019-2020.

\section{References}

Amir, N. (2014). Keamanan Pangan Produk Jambal Roti Ikan Manyung (Arius thalassinus Ruppell) Yang Terpapar Sipermetrin. Malang, Indonesia: Brawijaya University. Dissertation. [In Bahasa Indonesia].

Anihouvi, V.B., Kindossi, J.M. and Hounhouigan, J.D. (2012). Processing and Quality Characteristics of Some Major Fermented Fish Product from Africa: A Critical Review. International Research Journal of Biological Sciences, 1(7), 72-84

Apriyantono, A. (1989). Petunjuk Laboraturium Analisis Pangan. PAU Pangan dan Gizi. Bogor, Indonesia: Institut Pertanian Bogor. [In Bahasa Indonesia].

Association of Official Analytical Chemist (AOAC). (1970). Official Methods of Analysis. Maryland, USA: AOAC international.

Association of Official Analytical Chemist (AOAC). (1990). Official Methods of Analysis. Maryland, USA: AOAC international.

BSN-National Standardization Agency. (2009). Syarat Mutu Ikan Asin. Jakarta, Indonesia: BSN-National Standardization Agency. [In Bahasa Indonesia].

De-Angelis, M., Corsetti, A., Tosti, N., Rossi, J., Corbo, M.R. and Gobbetti, M. (2001). Characterization of non-starter lactic acid bacteria from Italian ewe cheeses based on phenotypic, genotypic, and cell wall protein analyses. Applied and Environmental Microbiology, 67(5), 2011-2020. https:// doi.org/10.1128/AEM.67.5.2011-2020.2001

Essuman, K.M. (1992). Fermented Fish in Africa. Rome: Food and Agriculture Organization of the United Nation.

Fadda, S., Yolanda, S., Graciella, V., M.-Concepción, A., Guillermo, O. dan Fidel, T. (1999).
Characterization of muscle sarcoplasmic and myofibrillar protein hydrolysis caused by Lactobacillus plantarum. Applied and Environmental Microbiology, 65(8), 3540-3546. https://doi.org/10.1128/AEM.65.8.3540-3546.1999

Fadda, S., Maria, J.V. and Graciella, V. (2010). The acidogenicmetabolisme of Lactobacillus plantarum CRL 681 improves sarcoplamic protein hydrolysing during meat fermentation. Journal of Muscle Protein, 21(3), 545-556. https://doi.org/10.1111/ j.1745-4573.2009.00202.x

Irianto, H.E. (2012). Produk Fermentasi Ikan. Jakarta, Indonesia: Penebar Swadaya. [In Bahasa Indonesia].

Mahulette, F., Mubarik, N.R., Suwanto, A. and Widanarni (2018). Microbiological and Physicochemical Characteristics of Inasua Traditional Fish Fermented from Maluku Islands. Biosaintifika Journal of Biology and Biology Education, 10(2), 298-305. https://doi.org/10.15294/ biosaintifika.v10i2.13537

Nadiah, I., Huda, N., Abdullah, W.N. and Al-Karkhi, A.F. (2014). Protein Quality of Fish Fermented Product: Budu and Rusip. Asia Pacific Journal of Sustainable Agriculture Food and Energy, 2(2), 1722

Nofiani, R., Elminah, E. and Ardiningsih, P. (2019). Chemical And Microbiological Properties of Buduk, A Commercial Fish Sauce from West Kalimantan. Jurnal Pengolahan Hasil Perikanan Indonesia, 22 (3), 601-608. https://doi.org/10.17844/ jphpi.v22i3.29230

Osman, O.A., Sulieman, A.M., Elkhalifa, E.A. and Mustafa, W.A. (2012). Chemical and Microbiological Characteristics of Fermented Fish product, Fassiekh. Food and Public Health, 2(6), 213-218

Pakpahan, R. (2009). Isolasi Bakteri dan Uji Aktivitas Bakteri Protease Termofilik Dari umber Air Panas Sipoholon Tapanuli Utara Sumatera Utara. Sumatera Utara, Indoneisa: Universitas Sumatera Utara. Thesis. [In Bahasa Indonesia].

Prihanto, A.A., Darius. and Firdaus, M. (2013). Proteolytic and Fibryolytic Activities of Halophilic Lactic Acid Bacteria from Two Indonesian Fermented Food. Journal of Microbiology, Biotechnology and Food Sciences, 2(5), 2291-2293.

Rahayu, E.S. (2003). Lactic Acid Bacteria in Fermented Food of Indonesia Origin. Agritech, 23(2), 75-84.

Rahayu, W.P., Ma'oen, S., Suliantari. and Fardiaz, S. (1992). Teknologi Fermentasi Produk Perikanan. Bogor, Indonesia: PAU Pangan dan Gizi, Institut Pertanian Bogor. [In Bahasa Indonesia]. 
Rinto. (2010). Effect of Addition of Pediococcus acidilactici F-11 and Salt on Microflora during Peda Fermentation. Jurnal Pengolahan Hasil Perikanan Indonesia, 8(1), 35-47. [In Bahasa Indonesia].

Sanni, A.I., Asiedu, M. and Ayernort. (2002). Microflora and Chemical of Momone, a Ghanaian Fermented Fish Condiment. Journal of Food Composition and Analysis, 15(5), 577-583. https://doi.org/10.1016/ S0889-1575(02)91063-X

Siddegowdaa, G.S., Bhaskarb, N. and Gopals, S. (2017) Fermentative Properties of Proteolytic Pediococcus Strains Isolated from Salt Fermented Fish Hydrolysate Prepared Using Freshwater Fish Rohu (Labeo rohita). Journal of Aquatic Food Product Technology, 26(3), 341-355. https:// doi.org/10.1080/10498850.2016.1185754

Sriphochanart, W. and Wanwisa, S. (2010). Characterization of proteolytic effect of lactic acid bacteria starter cultures on Thai fermented sausages. Food Biotechnology 24(4), 293-311. https:// doi.org/10.1080/08905436.2010.507163

Strahinic, I., Kojic, M., Tolinacki, M., Fira, D. and Topisirovic, L. (2010). The presence of prtP proteinase gene in natural isolate Lactobacillus plantarum BGSJ3-18. Letters in Applied Microbiology, 50(1), 43-49. https://doi.org/10.1111/ j.1472-765X.2009.02748.x

Sudarmadji, S., Bambang, S. and Suhardi. (1997). Prosedur Analisa untuk Bahan Makanan dan Pertanian. Yogyakarta, Indonesia: Liberty. [In Bahasa Indonesia].

Xu, Y., Wenshui, X., Fang, Y. and Xiahua, N. (2010). Physical and chemical changes of silver carp sausages during fermentation with Pediococcus pentosaceus. Food Chemistry, 122(3), 633-637. https://doi.org/10.1016/j.foodchem.2010.03.023

Yunita, S.P. (2012). Skrining dan Uji Aktivitas Enzim Protease Bakteri dari Limbah Rumah Pemotongan Hewan. Surabaya, Indonesia: Universitas Airlangga. BSc. Thesis. [In Bahasa Indonesia].

Yusufa, M.H., Padaga, M.C. and Octavianie, D.A. (2012). Identifikasi dan Studi Aktivitas Protease Bacillus sp Asal Limbah Cair Rumah Potong Ayam Tradisional Sebagai Kandidat Penghasil Biodeterjen. Malang, Indoensia: Universitas Brawijaya. Malang. BSc. Thesis. [In Bahasa Indonesia]. 